\title{
Diagnosis and validation by computational fluid dynamics of poultry house with negative pressure ventilation
}

\author{
Gisele C. de A. Cunha ${ }^{1}$, José P. Lopes Neto $^{2}$, Dermeval A. Furtado ${ }^{2}$, Valéria P. Borges ${ }^{3}$, \\ Elias A. Freire ${ }^{1} \&$ José W. B. do Nascimento ${ }^{2}$
}

${ }^{1}$ Instituto Federal de Educação, Ciência e Tecnologia da Paraíba. Campina Grande, PB, Brasil. E-mail: gisele.araujo@ifpb.edu.br (Corresponding author) - ORCID: 0000-0002-1537-6823; elias.a.freire@gmail.com - ORCID: 0000-0003-3481-8524

${ }^{2}$ Universidade Federal de Campina Grande/Unidade Acadêmica de Engenharia Agrícola. Campina Grande, PB, Brasil. E-mail: lopesneto@gmail.com ORCID: 0000-0003-4960-5679; araujodermeval@gmail.com - ORCID: 0000-0003-4511-571X; wallacebosa@hotmail.com - ORCID: 0000-0002-8376-0173

${ }^{3}$ Universidade Federal da Paraíba/Centro de Ciências Agrárias. Areia, PB, Brasil. E-mail:valpborges@gmail.com - ORCID: 0000-0002-2368-245X

\begin{abstract}
Negative pressure ventilation in poultry houses has been used to enable the correction of their internal microclimates, and studies point to the heterogeneous distribution of air along the aviaries and the inadequacy of the environmental variables to the recommended ranges for thermal comfort of adult birds, especially in the hottest hours of the day. This study aimed to diagnose the facilities of a poultry house in the state of Paraíba, Brazil, regarding the distribution of environmental variables and thermal comfort; develop a computational model and validate it for Computational Fluid Dynamic - CFD simulations. Air temperature $\left(\mathrm{T}_{\text {air }}\right)$, air relative humidity $(\mathrm{RH})$ and air velocity $\left(\mathrm{V}_{\text {air }}\right)$ data allowed characterizing the internal environment by comparison with the recommended ranges for each variable and by the temperature-humidity-velocity index (THVI). The poultry house does not provide comfort for the housed adult birds, between 12 and $14 \mathrm{~h}$, with THVI indicating alert and $\mathrm{T}_{\text {air }}$, $\mathrm{RH}$ and $\mathrm{V}_{\text {air }}$ values outside the recommended ranges; the CFD model for the poultry house was validated with $\mathrm{T}_{\text {air }}$ averages collected in the field of $27.75 \pm 1.35^{\circ} \mathrm{C}$ and simulated of $27.85 \pm 0.55{ }^{\circ} \mathrm{C}$, mean values of RH collected of $83 \pm 12 \%$ and simulated of $78 \pm 3 \%$, and means of $\mathrm{V}_{\text {air }}$ collected of $2.35 \pm 1.35 \mathrm{~m} \mathrm{~s}^{-1}$ and simulated of $2.50 \pm 1.50 \mathrm{~m} \mathrm{~s}^{-1}$.
\end{abstract}

Key words: thermal comfort, thermal index, simulations

\section{Diagnóstico e validação por dinâmica de fluidos computacional de aviário com ventilação à pressão negativa}

RESUMO: A ventilação à pressão negativa em aviários vem sendo utilizada para viabilizar a correção de seus microclimas internos, sendo que pesquisas apontam para a distribuição heterogênea do ar ao longo dos galpões e inadequação das variáveis ambientais às faixas recomendadas para o conforto térmico de aves adultas, especialmente nas horas mais quentes do dia. Objetivou-se, neste estudo, diagnosticar as instalações de um aviário no estado da Paraíba, quanto à distribuição das variáveis ambientais e ao conforto térmico, desenvolver um modelo computacional e validá-lo mediante simulações utilizando dinâmica de fluidos computacional - DFC. O registro da temperatura do ar $\left(\mathrm{T}_{\mathrm{ar}}\right)$, umidade relativa do ar (UR) e velocidade do vento $\left(\mathrm{V}_{\mathrm{v}}\right)$ permitiu caracterizar o ambiente interno por comparação com as faixas recomendadas para cada variável e por meio do índice de temperatura, umidade e velocidade do vento (ITUV). O galpão não provem conforto às aves adultas alojadas, entre $12 \mathrm{e} 14 \mathrm{~h}$, com ITUV indicativo de alerta e valores de $T_{\mathrm{ar}}, \mathrm{UR} \mathrm{e}_{\mathrm{v}}$ não pertinentes às faixas recomendadas; o modelo DFC do aviário foi validado com médias de $\mathrm{T}_{\mathrm{ar}}{ }^{\mathrm{ar}}$ coletadas em campo de $27,75 \pm 1,35^{\circ} \mathrm{C}$ e simuladas de $27,85 \pm 0,55^{\circ} \mathrm{C}$, médias de UR coletadas de $83 \pm 12 \%$ e simuladas de $78 \pm 3 \%$ e médias de $\mathrm{V}_{\mathrm{v}}$ coletadas de $2,35 \pm 1,35 \mathrm{~m} \mathrm{~s}^{-1}$ e simuladas de $2,50 \pm 1,50 \mathrm{~m} \mathrm{~s}^{-1}$.

Palavras-chave: conforto térmico, índice térmico, simulações

Ref. 206853 - Received 06 Jul, 2018• Accepted 23 Aug, 2019 • Published 28 Aug, 2019 


\section{INTRODUCTION}

The most prominent Brazilian agricultural activity in the world scenario is poultry farming. The country, in 2016, was the main exporter and the second in the ranking of the largest producers of chicken meat in the world (ABPA, 2016) and, although the negative pressure ventilation in aviaries is employed in countries of tropical and temperate climate such as Brazil, USA and Korea (Bustamante et al., 2015), in the Paraíba state, Brazil, it is being incorporated as a way to improve the production levels by correcting the internal microclimate of the facilities. Furtado et al. (2003) concluded that, in the Agreste Paraibano mesoregion, the positive pressure systems, although equipped with nebulizers, were inefficient to maintain ideal thermal conditions for broilers, subjecting them to heat stress, especially in the hottest hours of the day.

Although the negative pressure ventilation associated with adiabatic cooling can mitigate the deleterious effect of high temperatures, it is not always efficient to guarantee uniformity regarding the distribution of environmental variables (Curi et al., 2017a, b).

In order to optimize the control of internal thermal conditions, diagnosis and validation studies, in which results of fluid simulations were compared to measurements collected in the field, have been carried out (Blanes-Vidal et al., 2008; Bustamante et al., 2013; Hernández et al., 2013; Xue et al., 2016; Curi et al., 2017b). Validated computational fluid dynamics (CFD) models can contribute to reducing time and cost with repetitions in experiments and improving poultry house facilities from parametric simulations, besides providing information on the whole internal environment, whereas field measurements are limited (Bustamante et al., 2015).

Therefore, this study aimed to diagnose the distribution of air temperature, air relative humidity and air velocity, and to characterize the thermal environment of a poultry house ventilated using negative pressure, in addition to developing and validating a computational fluid dynamic model of this poultry house regarding their distribution.

\section{Material ANd Methods}

Field data collection was carried out in a poultry house belonging to Guaraves Alimentos Ltda., located in Guarabira, $\mathrm{PB}$, Brazil (6 $6^{\circ} 51^{\prime} 58^{\prime \prime} \mathrm{S} ; 35^{\circ} 27^{\prime} 58^{\prime \prime} \mathrm{W}$; $89 \mathrm{~m}$ of altitude). The company's control data indicated the housing of 30,000 chickens (13.33 birds $\mathrm{m}^{-2}$ ) on March 22, 2016, removal of 10,000 females at 32 days of housing and the end of the production cycle at 42 days, when the average weight of $2.60 \mathrm{~kg}$ animal $^{-1}\left(\sim 23.0 \mathrm{~kg} \mathrm{~m}^{-2}\right)$ and final mortality rate of $0.02 \%$ (613 units) were recorded.

Located in the Agreste Paraibano mesoregion, Guarabira has sub-humid tropical climate (Aw'), according to Köppen's classification, with maximum average temperature of $32{ }^{\circ} \mathrm{C}$ (from November to February) and minimum temperature of $19.5^{\circ} \mathrm{C}$ (in August), average air relative humidity of 71.5 to $84.7 \%$ in November and June, respectively, predominant winds with Southeast direction and average air velocity, calculated at $2 \mathrm{~m}$ from the ground, of $8.77 \mathrm{~m} \mathrm{~s}^{-1}$ (DCA, 2016).
The poultry house used as experimental environment or prototype, with East-West orientation, was $15 \mathrm{~m}$ wide, $150 \mathrm{~m}$ long $\left(2,250.00 \mathrm{~m}^{2}\right)$, ceiling height varying between 2.30 and $3.90 \mathrm{~m}$, $0.40 \mathrm{~m}$ high walls, eaves between 0.60 and $0.90 \mathrm{~m}$ (North and South) and $2.15 \mathrm{~m}$ (East), wall in ceramic bricks and flexible closures in yellow polypropylene, steel structure with metal roof cover and ceiling (parallel to the cover) made of $0.02 \mathrm{~m}$ thick polyurethane plates (Figure 1A). The covering system was also equipped with 24 air deflectors in yellow polypropylene fixed onto the structural porticos, spaced by $6.00 \mathrm{~m}$ (Figure 1B).

The ventilation system, with negative pressure, dimensioned for air velocities of up to $3.5 \mathrm{~m} \mathrm{~s}^{-1}$ had: a) air inlet by two evaporative pads ( $16.80 \mathrm{~m}$ long and $1.80 \mathrm{~m}$ high each) on Munters CELdek 7090-15-1800-600-100 cellulose sheets, located on the North and South sides, close to the East front gable; b) Air output by 10 fans made of galvanized steel, Multifan 130 (1.38 m diameter), power of $1.5 \mathrm{HP}(\sim 1120 \mathrm{~W})$ and flow rate of $47.470 \mathrm{~m}^{3} \mathrm{~h}^{-1}$ at $0 \mathrm{~Pa}$, eight located to the West, one to the North and the other to the South; these two next to the back gable. During the measurement period, all exhaust fans were in operation between 12 and $14 \mathrm{~h}$.

Data of air temperature $\left(\mathrm{T}_{\text {air }}\right)$, air relative humidity $(\mathrm{RH})$ and air velocity $\left(\mathrm{V}_{\text {air }}\right)$ were simultaneously collected inside the poultry house, every $5 \mathrm{~min}$, between April 23 and May 1, 2016 (from the $33^{\text {rd }}$ to $41^{\text {st }}$ day of the birds' production cycle). Among the validated data, those between 12 and $14 \mathrm{~h}$ (all the exhaust fans in operation) of the $34^{\text {th }}, 36^{\text {th }}$ and $38^{\text {th }}$ days. For this purpose, four measuring sets were used, each one composed of: development platform (Arduino Mega 2560 ${ }^{\circ}$ ), voltage divider board, card module (SD Card), memory card (8 MB), six hotwire wind sensors (Wind Sensor Rev C, Modern Device) and four humidity and temperature sensors (DHT22/AM2302). In total, 16 sensors of wind, humidity and temperature were fixed at $0.50 \mathrm{~m}$ height from the bedding (sensors 1, 2, 3 and 4) and eight more wind sensors fixed at $1.50 \mathrm{~m}$ height (sensors 5 and 6), as shown in Figure 2. The latter sensors were used
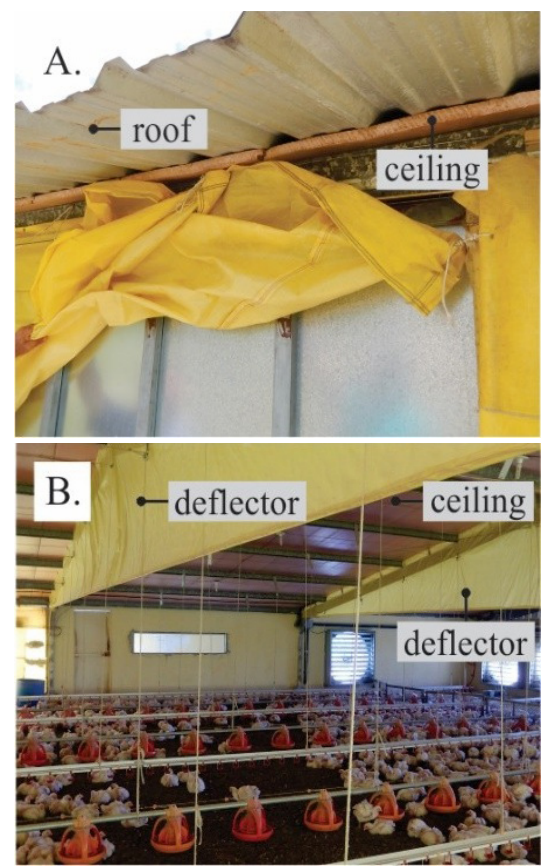

Figure 1. Details of flexible closing, roof and ceiling (A) and air deflectors and ceiling (B) 


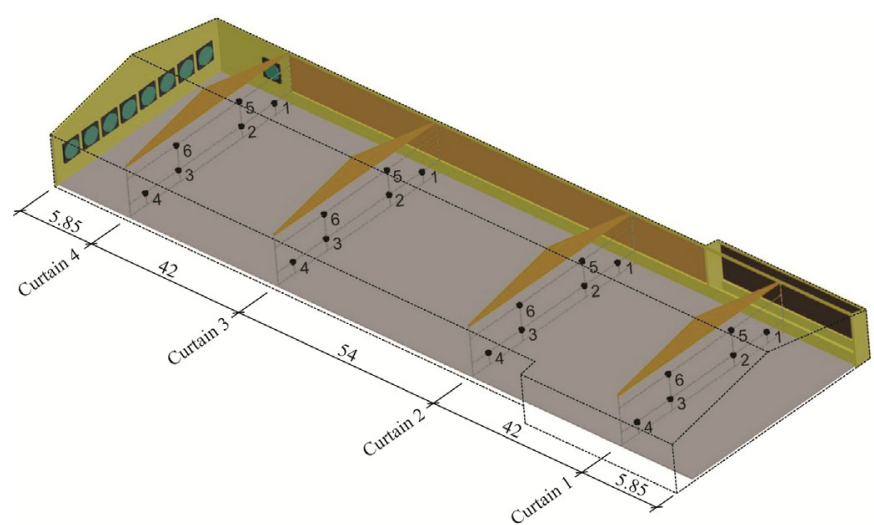

Distances in $\mathrm{m}$

Figure 2. Schematic location of the data acquisition system sensors

mainly for validating the model for CFD analysis. More details of instrumentation and data collection can be found in Cunha (2017).

In order to feed the CFD simulation model, the Instrutherm THAL 300 thermo-hygro-anemometer was used to collect complementary data of: a) air temperature outside the house at a central point $5.00 \mathrm{~m}$ away from the East wall; b) air temperature and air relative humidity at 10 equidistant points $0.10 \mathrm{~m}$ away from the evaporative pads on the inside of the house; c) air velocity outside of each exhaust fan, at four points aligned, from the center to the end, $0.10 \mathrm{~m}$ away from the cone. These data were obtained from a single daily collection, initiated at $13 \mathrm{~h}$, on the $34^{\text {th }}, 36^{\text {th }}$ and $38^{\text {th }}$ days of housing of the birds.

The diagnosis of the poultry house was made by initially comparing the collected data of $\mathrm{T}_{\text {air }}, \mathrm{RH}$ and $\mathrm{V}_{\text {air }}$ with the recommended limits for thermal comfort of adult birds: $18 \leq \mathrm{T}_{\text {air }} \leq 28^{\circ} \mathrm{C}$ and $50 \leq \mathrm{RH} \leq 70 \%$ (Abreu \& Abreu, 2011) and $1.75 \leq \mathrm{V}_{\text {air }} \leq 3.00 \mathrm{~m} \mathrm{~s}^{-1}$ (Cobb Brasil, 2012). Then, the thermal environment was characterized using the THVI (Tao \& Xin, 2003) according to Eq. 1.

$$
\text { THVI }=\left[\left(0.85 \mathrm{~T}_{\text {air }}\right)+\left(0.15 \mathrm{~T}_{\mathrm{wb}}\right)\right] \mathrm{V}_{\text {air }}^{-0.058}
$$

where:

THVI - temperature-humidity-velocity index;

$\mathrm{T}_{\text {air }} \quad$ - air temperature, ${ }^{\circ} \mathrm{C}$;

$\mathrm{T}_{\mathrm{wb}}$ - wet bulb temperature, ${ }^{\circ} \mathrm{C}$; and,

$\mathrm{V}_{\text {air }}$ - air velocity, $\mathrm{m} \mathrm{s}^{-1}$.

For THVI, the interpretative ranges proposed by Angelo et al. (2014) were considered, since the values of the environmental variables collected were consistent with the conditions tested by these authors. Thus, THVI $\leq 24$ was considered as an indication of comfort and $24<$ THVI $\leq 34$ as an indication of alert situations.

A real-scale reference model, generated by similitude with the prototype, was created with Autodesk AutoCAD 2014 (student version I.18.0.0) and exported as ACIS file (*.sat) to the Autodesk CFD (2016) environment (student version 16.2) to perform the CFD simulations. Structural elements and fluid regions not directly involved in the problem were excluded from the geometry of the poultry house. Evaporative pads, flexible vertical closures and air deflectors were modeled as two-dimensional regions (without thickness) in order to reduce mesh refinement, the quantity of nodes and the number of total elements. Following the recommendations of the Autodesk CFD (2016), to represent the air entering and exiting the building, volumes adjacent to the external faces of evaporative pads and exhaust fans (Figure 3 ) were generated.

Then, all building materials were defined based on their physical-thermal properties and applied to the corresponding part of the geometry. The evaporative pads were treated as porous media and, for that, the coefficient describing the losses in terms of pressure drop (Eq. 2) was calculated:

$$
\Delta \mathrm{p}=\zeta_{\mathrm{i}} \rho\left(\mathrm{V}_{\mathrm{i}}^{2} / 2\right)
$$

where:

$\Delta \mathrm{p}$ - pressure variation, $\mathrm{Pa}$

$\zeta_{\mathrm{i}} \quad$ - coefficient of loss in the overall direction i, dimensionless;

$\rho \quad$ - fluid density, $\mathrm{kg} \mathrm{m}^{-3}$; and,

$\mathrm{V}_{\mathrm{i}} \quad$ - fluid velocity in the overall direction $\mathrm{i}, \mathrm{m} \mathrm{s}^{-1}$.

The boundary conditions responsible for the flow simulation were: a) mass flow rate, applied to the output air volumes were calculated based on the average value of the air velocities observed on the external side of the exhaust fans; b) static pressure equal to zero, applied to the surfaces of the input air volumes, to simulate the effect of negative pressure ventilation. The boundary conditions responsible for allowing heat exchange were: a) reference temperature, to characterize the external environment in the simulation; b) film coefficient, applied to all external surfaces of the envelopment, to simulate the external air in motion; c) air temperature and air relative humidity, resulting from the average values found close to the evaporative pads, attributed to the input air volumes; d) total heat generation, juxtaposed to the receptacles of the exhaust fans and calculated by multiplying the amount of devices by their power; e) total heat flow, attributed to the upper side of the representative volume of broilers and estimated by multiplying the final number of live birds by the basal metabolic rate per animal. Heat production by the birds was calculated based on the basal metabolic rate per animal (Curtis, 1983) multiplied by the final average weight of all birds (19,387 live birds with average weight of $\left.2.60 \mathrm{~kg} \mathrm{bird}^{-1}\right)$.

For automatic mesh refinement in the three-dimensional elements, the following parameters were fixed: a) limit size of

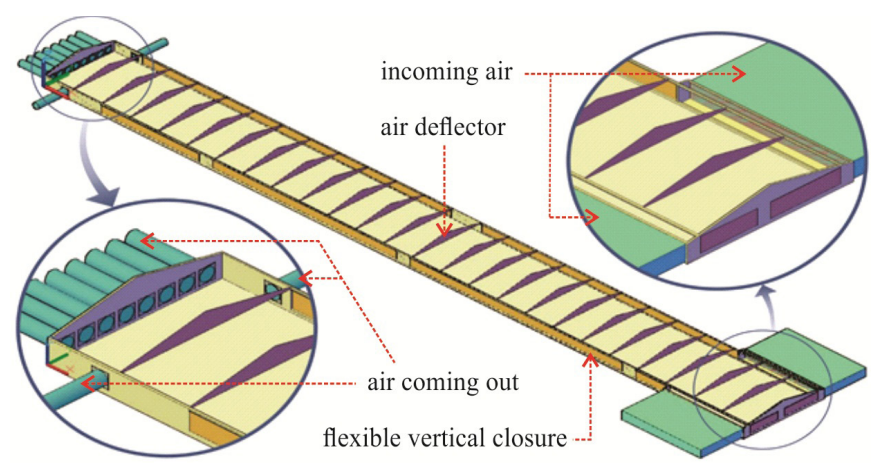

Figure 3. Perspective and internal details of the reference model for validation 
the edge at $0.10 \mathrm{~m}$, corresponding to the thickness of the roof/ ceiling set; b) number of eight layers of elements along the fluid-wall/solid interfaces; and c) growth rate and smoothing of the transition between layers and adjacent mesh equal to 1.50. As a parameter for mesh refinement in the two-dimensional elements, the value 10 was established for the boundary of the surface aspect ratio.

The solution calculation mechanism was configured as steady state, with a maximum of 1500 iterations up to convergence. The ADV01 advection scheme was used, due to the existence of two-dimensional elements. The flow was determined as incompressible and turbulent, with "Standard k- $\varepsilon$ " turbulence model, available in Autodesk CFD (2016).

The validation of the reference model for the variables $\mathrm{T}_{\text {air }}$, $\mathrm{RH}$ and $\mathrm{V}_{\text {air }}$ was performed by comparing the simulation results and their correspondents obtained experimentally. A procedure adopted by Saraz et al. (2011); Xue et al. (2016) and Curi et al. (2017b) was used, in which the normalized mean squared error (NMSE) is calculated according to Eq. 3, and NMSE values less than 0.25 are acceptable as good indicators of agreement.

$$
\mathrm{NMSE}=\left(\frac{\Sigma_{\mathrm{i}}\left(\mathrm{V}_{\mathrm{pi}}-\mathrm{V}_{\mathrm{mi}}\right)^{2}}{\mathrm{n}}\right) /\left(\mathrm{mV}_{\mathrm{pi}} \mathrm{mV}_{\mathrm{mi}}\right)
$$

where:

NMSE - normalized mean squared error;

$\mathrm{V}_{\mathrm{pi}}$ - value of the predicted environmental variable, $\mathrm{m} \mathrm{s}^{-1}$;

$\mathrm{V}_{\mathrm{mi}}$ - value of the measured environmental variable, $\mathrm{m} \mathrm{s}^{-1}$; $\mathrm{m} \mathrm{s}^{-1}$;

$\mathrm{mV}_{\mathrm{pi}}$ - mean value of the predicted environmental variable,

$\mathrm{mV}_{\mathrm{mi}}$ - mean value of the measured environmental variable, $\mathrm{m} \mathrm{s}^{-1}$; and,

$\mathrm{n} \quad$ - number of measurements, dimensionless.

\section{Results AND Discussion}

The mean values of air temperature observed in the poultry house were: minimum $\mathrm{T}_{\text {air }}$ of $26.4^{\circ} \mathrm{C}$ was recorded in Curtain 1, whereas maximum $\mathrm{T}_{\text {air }}$ of $29.1^{\circ} \mathrm{C}$ was recorded in Curtain 4; the overall mean air temperature was $28.2^{\circ} \mathrm{C}$; the means per alignment were 27.2 and $28.0^{\circ} \mathrm{C}$ in Curtains 1 and 2 and $28.8^{\circ} \mathrm{C}$ in Curtains 3 and 4 (Figure 4A). The mean values of air relative humidity observed in the poultry house were: $\mathrm{RH}$ values of 84.3, 89.0, 93.0 and 72.3\% were recorded in Curtains from 1 to 4 , respectively, with an overall mean value of $84.7 \%$. Close to
Curtain 3, the RH reached a maximum value of $95 \%$, whereas in Curtain 4 , immediately after in the sequence, a minimum value of $71 \%$ was recorded (Figure 4B).

These findings corroborate the records of Santos (2012), who found maximum values of $\mathrm{T}_{\text {air }}$ and $\mathrm{RH}$ of up to $35.5^{\circ} \mathrm{C}$ and 91.2\%; whereas the mean values of $\mathrm{T}_{\text {air }}$ and $\mathrm{RH}$ were $28.3^{\circ} \mathrm{C}$ and $76.2 \%$, respectively, during the $6^{\text {th }}$ and $7^{\text {th }}$ week of the poultry production cycle, in two poultry houses with negative pressure ventilation, in Guarabira, PB, Brazil. Furtado et al. (2003) found $\mathrm{T}_{\text {air }}$ between 28.7 and $30.9^{\circ} \mathrm{C}$, between 12 and $14 \mathrm{~h}$, in poultry houses in the Paraíba state, Brazil, with different acclimatization systems. Curi et al. (2017a) cited a maximum of $90 \%$ and a mean of $82.9 \%$ in tunnel ventilated poultry houses in the city of Amparo, SP, Brazil.

It was verified that $\mathrm{T}_{\text {air }}$ values were within the limits recommended in Abreu \& Abreu (2011) as comfortable for adult broilers, only in the section close to the evaporative pad. Furtado et al. (2003) stated that, in the various mesoregions of the Paraíba state, Brazil, adult birds suffered heat discomfort inside artificially ventilated poultry houses in the daytime period.

The increase in the magnitude of air temperature, with the distance from the pads and proximity to the exhaust fans, reveals a pattern also found by Franco et al. (2011). As the $\mathrm{T}_{\text {air }}$ outside the poultry house was $34.5^{\circ} \mathrm{C}$, the evaporative pads contributed to the average cooling of $7.3^{\circ} \mathrm{C}$. Franco et al. (2011) and Carvalho et al. (2009) state that air cooling by evaporative pads can lead to a reduction of up to $11^{\circ} \mathrm{C}$ compared to the external temperature.

The heating of the air along the poultry house, among other factors, was due to the production of metabolic heat totaling $137,000 \mathrm{~W}$ and the increment of the heat loads originated from the electric exhaust fans estimated at 11,200 W.

In the hottest hours of the day, $\mathrm{RH}$ was closer to the recommended limit for the comfort of adult broilers in Curtain 4 and, despite that, with values outside the range from 50 to $70 \%$ recommended by Abreu \& Abreu (2011).

The air relative humidity increased in the middle portions of the poultry house, referring to Curtains 2 and 3, because the complementary internal system of nebulization remained turned off in the section corresponding to the evaporative pads and in the section close to the exhaust fans. In the latter, as a protective measure for electrical equipment, the air relative humidity resulted only from the transport by the wind minus the portion lost due to the higher temperature at the back of the poultry house.

Lower air velocities, with a mean value of $1.13 \mathrm{~m} \mathrm{~s}^{-1}$, occurred in the alignment of Curtain 1; for Curtains 2, 3 and
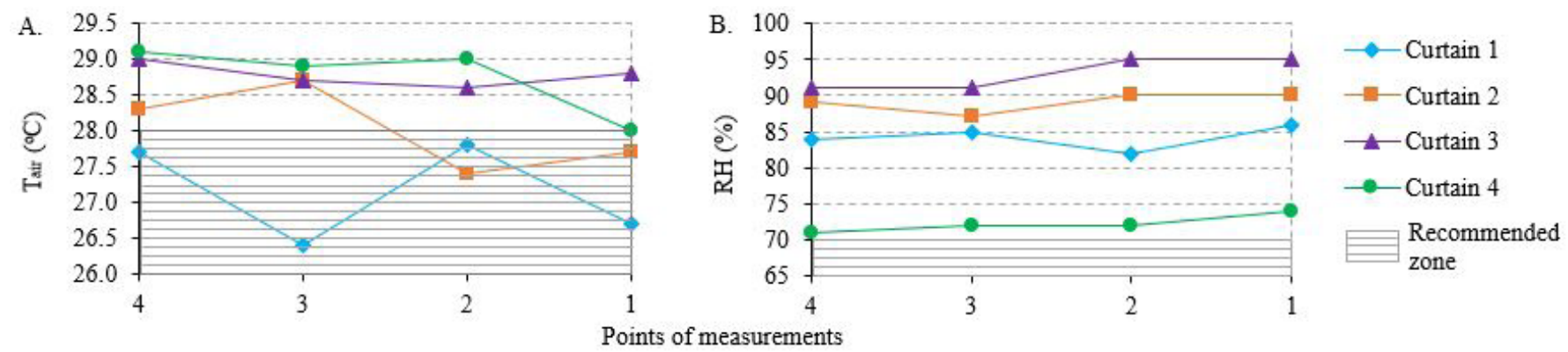

Figure 4. Means and curves generated for air temperature - $\mathrm{T}_{\text {air }}(\mathrm{A})$ and air relative humidity - $\mathrm{RH}(\mathrm{B})$ collected at $0.5 \mathrm{~m}$ height 
4 , the mean values of the variable in question were $3.52,3.40$ and $3.33 \mathrm{~m} \mathrm{~s}^{-1}$, respectively. The following values were found: minimum of $1.00 \mathrm{~m} \mathrm{~s}^{-1}$, maximum of $3.90 \mathrm{~m} \mathrm{~s}^{-1}$, with averages of $2.90 \mathrm{~m} \mathrm{~s}^{-1}$ at $0.50 \mathrm{~m}$ height (Figure $5 \mathrm{~A}$ ), $2.73 \mathrm{~m} \mathrm{~s}^{-1}$ at $1.50 \mathrm{~m}$ height and overall average of $2.85 \mathrm{~m} \mathrm{~s}^{-1}$ (Figure $5 \mathrm{~B}$ ).

It is possible to note the inadequacy of the $\mathrm{V}_{\text {air }}$ data found throughout the air volume in the poultry house by the values outside the range recommended by Cobb Brasil (2012) for the thermal comfort of adult birds. Although the mean value is appropriate for the comfort of adult broilers, the large amplitude between maximum and minimum values should be considered relevant; the latter much below the recommended lower limits.

Curi et al. (2017a) reported maximum $\mathrm{V}_{\text {air }}$ of $2.32 \mathrm{~m} \mathrm{~s}^{-1}$ and minimum of $0.34 \mathrm{~m} \mathrm{~s}^{-1}$ found in barns of Amparo, SP, Brazil, at 42 days of life of the birds, in the summer period, at 14 h. Santos (2012) reported minimum air velocity of $0 \mathrm{~m} \mathrm{~s}^{-1}$ and maximum of $2.90 \mathrm{~m} \mathrm{~s}^{-1}$, in the $6^{\text {th }}$ week of life of birds in poultry houses ventilated with negative pressure located in Guarabira, PB, Brazil.

Air velocity showed a more uniform distribution in the section immediately after the alignment of the evaporative pads, with a mean difference of approximately $300 \%$ between the data of Curtain 1 and the subsequent ones.

The minimum temperature humidity velocity index (THVI) calculated for points at $0.50 \mathrm{~m}$ height was 25.3 in Curtain 2, and maximum THVI of 27.4 in Curtain 1. The overall mean THVI was 26.3 (Figure 6). The similarity between THVI curves and $\mathrm{T}_{\text {air }}$ curves presented in Figure 4 shows the greater importance of this variable compared to $\mathrm{RH}$ and $\mathrm{V}_{\text {air }}$.

The internal environment was inadequate, according to the THVI, to ensure thermal comfort for the housed birds in the hottest hours of the day, even if the ventilation system was being used at its maximum power, which agrees with the studies of Furtado et al. (2003) and Santos (2012), who employed the Black Globe Temperature and Humidity Index - BGTHI to characterize the thermal environment of poultry houses in Paraíba state, Brazil, and found maximum BGTHI of 80 and 80.4 , respectively, indicating stress situation for the birds in the finishing phase.

Based on the diagnosis for the instrumented poultry house, it is inferred that reducing RH levels to $50 \%$ would be the easiest measure to be implemented in order to improve the thermal sensation of the broilers during the hottest hours of the day. Therefore, keeping the internal nebulization system off seemed to be the correct alternative.

The automatically generated mesh, from the finite element method of discretization, was non-structured, predominantly

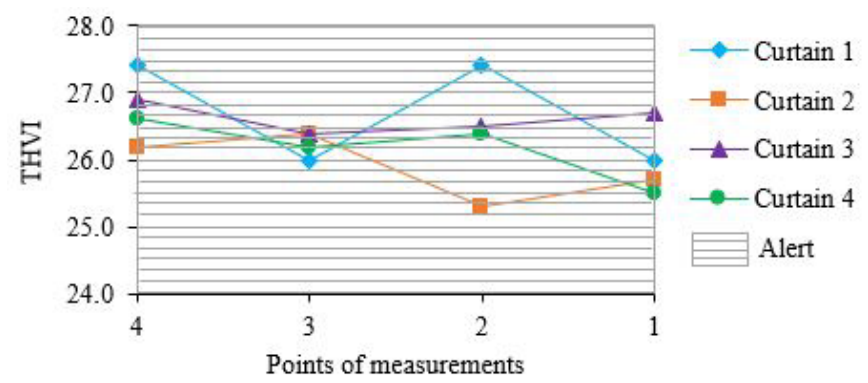

Figure 6. Means and curves generated for temperature humidity velocity index (THVI) means calculated at $0.50 \mathrm{~m}$ height

tetrahedral, composed of 973,495 nodes and 3,524,459 elements distributed in the model, with a volume of $8,056.6 \mathrm{~m}^{3}$, with maximum nodal aspect ratio of 11.52, and 1,060 iterations were required to achieve convergence. According to Autodesk CFD (2016), nodal aspect ratio lower than 100 is a good indication of mesh suitability. One of the criteria defined for automatic convergence detection was the residual value (RMS) lower than $10^{-5}$, suggested for Standard K- $\varepsilon$ models.

The CFD model was validated by calculating the NMSE for each Curtain (1, 2, 3 and 4) separately and for the environment as a whole. The maximum value calculated for NMSE per variable was 0.19 , for air relative humidity, in Curtain 3, whereas the overall maximum was 0.13 , also for $\mathrm{RH}$. The overall NMSE was equal to 0.00 for $\mathrm{T}_{\text {air }}$ and to 0.02 for $\mathrm{V}_{\text {air }}$.

Xue et al. (2016) calculated the average NMSE of 0.15 and considered its CFD model to be valid for analyzing the effects of cooling pad installation on airflow distribution in tunnelventilated laying-hen houses. Curi et al. (2017b) found NMSE equal to 0.19 for air velocity and validated a CFD model, generated in Ansys CFX 14.0 software, of a broiler house ventilated with negative pressure. Saraz et al. (2011) found a maximum NMSE of 0.0035 for air temperature and validated a simulation model to estimate air temperature distribution in poultry house with tunnel ventilation system.

Thus, the CFD model for the prototype was also considered validated and, therefore, the procedures and configurations of its CFD modeling were declared adequate for application in other parametric simulations.

However, the partial NMSE values referring to $\mathrm{RH}$ in curtains 2 and 3, 0.06 and 0.19 respectively, call the attention. When the minimum and maximum values of $\mathrm{RH}$ were compared, it was possible to observe how less uniform the distribution of this variable was for the collected data: while local measurements recorded overall mean values of $83 \pm$ $12 \%$, those originating from the CFD simulation indicated
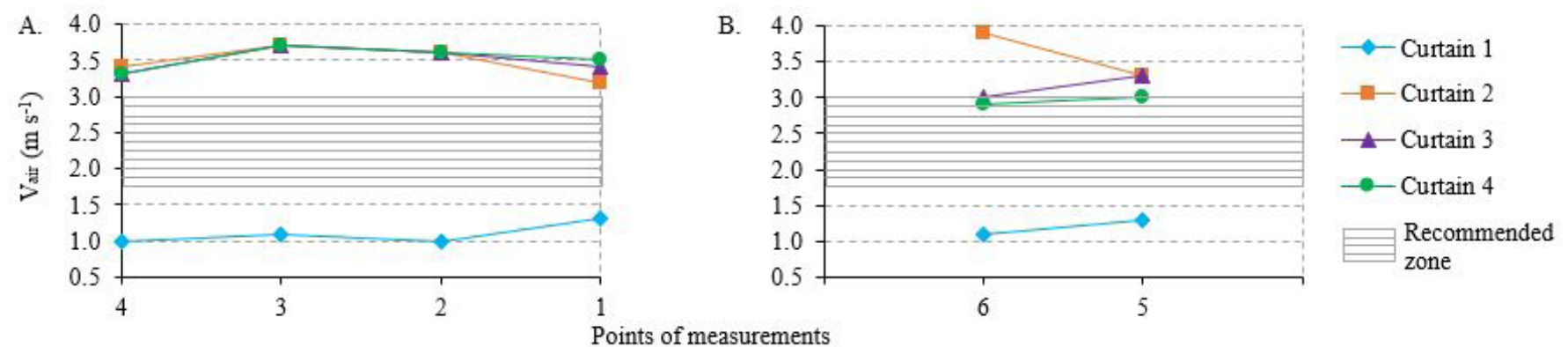

Figure 5. Means and curves generated for air velocity $\left(\mathrm{V}_{\text {air }}\right)$ collected at $0.50 \mathrm{~m}(\mathrm{~A})$ and $1.50 \mathrm{~m}(\mathrm{~B})$ heights 
variation of about $78 \pm 3 \%$. As suggested by the partial NMSE calculated, such distortion between collected and simulated results became more evident in curtains 2 and 3. In curtain 2, the percentage difference between minimum values was $9.2 \%$ and between maximum values was $12.2 \%$; in curtain 3 , this difference was $17.6 \%$ for the minimum values and $21 \%$ for the maximum values.

The minimum and maximum air temperatures collected at $0.50 \mathrm{~m}$ were 26.4 and $29.1^{\circ} \mathrm{C}$, whereas the simulated values at the same height were 27.3 and $28.4^{\circ} \mathrm{C}$. Thus, the overall mean values were $27.75 \pm 1.35^{\circ} \mathrm{C}$ in the field data and $27.85 \pm 0.55{ }^{\circ} \mathrm{C}$ in the simulation.

The minimum and maximum air velocities collected at $0.50 \mathrm{~m}$ were 1.0 and $3.7 \mathrm{~m} \mathrm{~s}^{-1}$, respectively, and the simulated values were 1.0 and $4.0 \mathrm{~m} \mathrm{~s}^{-1}$. At $1.50 \mathrm{~m}$ height, these data were 1.1 and 3.9 and 1.2 and $3.4 \mathrm{~m} \mathrm{~s}^{-1}$, respectively, for collected and simulated data. The results indicated variations of $2.35 \pm 1.35 \mathrm{~m} \mathrm{~s}^{-1}$ in the air velocity measured in the poultry house at $0.50 \mathrm{~m}$ and of $2.50 \pm 1.50 \mathrm{~m} \mathrm{~s}^{-1}$ in the simulated values; at $1.50 \mathrm{~m}$ height, the overall mean values collected at the site were $2.50 \pm 1.40 \mathrm{~m} \mathrm{~s}^{-1}$ and the simulated values were $2.30 \pm 1.10 \mathrm{~m} \mathrm{~s}^{-1}$. The simulated velocities at $0.50 \mathrm{~m}$ were always higher than those collected, except for the measurement relative to the point 1 of Curtain 1 . This pattern could not be identified at $1.50 \mathrm{~m}$ height. One hypothesis is that, in the alignment just below the air deflectors, there is a turbulence zone. In this case, the use of REV C-type wind sensors, efficient for measurements in unidirectional winds, may not be adequate.

The variations between the means of collected and the simulated data, in the present experiment, are similar to the results found by Blanes-Vidal et al. (2008) and Bustamante et al. $(2013,2015)$, provided that the singularities of each study are considered. Bustamante et al. (2015), studying the importance of operating patterns of the exhaust fans on the air velocity distribution in broiler house in Alcalá de Xivert/Spain, found an average velocity of $1.57 \pm 0.70 \mathrm{~m} \mathrm{~s}^{-1}$ for collected data and $1.62 \pm 0.73 \mathrm{~m} \mathrm{~s}^{-1}$ for simulated data. Bustamante et al. (2013) explored the internal environment of a broiler building in Villa Real, Spain, and considered as valid the CFD simulations in which the mean values of air velocity were $0.64 \pm 0.54 \mathrm{~m} \mathrm{~s}^{-1}$ for direct measurements and $0.60 \pm 0.56 \mathrm{~m} \mathrm{~s}^{-1}$ for CFD. Blanes-Vidal et al. (2008), in their experiment in the city of Valencia, Spain, found air velocity at the height of the birds of $0.37 \pm 0.14 \mathrm{~m} \mathrm{~s}^{-1}$ for data obtained from measurements and $0.34 \pm 0.13 \mathrm{~m} \mathrm{~s}^{-1}$ from the adjustment of CFD simulations.

\section{Conclusions}

1. The diagnosis of the poultry house indicated the inefficiency of the climatization in providing thermal comfort for the housed adult birds, between 12 and $14 \mathrm{~h}$. The thermal environment was characterized by temperature humidity velocity index (THVI) as "alert situation".

2. The air temperature $\left(\mathrm{T}_{\text {air }}\right)$ was within the comfort zone only in the section corresponding to the evaporative pads; the air relative humidity $(\mathrm{RH})$ was above the recommended range along the entire poultry house; the air velocity $\left(\mathrm{V}_{\text {air }}\right)$ was always below the recommended range in the section relative to the evaporative pads and higher in the other sections.
3. The computational fluid dynamics (CFD) model based on the prototype was validated, with overall maximum normalized mean squared error (NMSE) of 0.13 for RH; overall NMSE was equal to 0 for $\mathrm{T}_{\text {air }}$ and to 0.02 for $\mathrm{V}_{\text {air }}$.

\section{Literature Cited}

ABPA - Associação Brasileira de Proteína Animal. Relatório anual - 2016. Available on: <http://abpa-br.com.br/storage/files/ versao_final_para_envio_digital_1925a_final_abpa_relatorio_ anual_2016_portugues_web1.pdf>. Accessed on: Dec. 2016.

Abreu, V. M. N.; Abreu, P. G. de. Os desafios da ambiência sobre os sistemas de aves no Brasil. Revista Brasileira de Zootecnia, v.40, p.1-14, 2011.

Angelo, M. S. P. de; Nääs, I.; Vendrametto, O. Programa computacional para a estimativa de conforto térmico na produção intensiva de suínos e frangos de corte. Engenharia na Agricultura, v.22, p.535-542, 2014. https://doi.org/10.13083/1414-3984.v22n06a04 Autodesk CFD. Help. Available on: <http://help.autodesk.com/view/ SCDSE/2016/ENU/>. Accessed on: Dec. 2016.

Blanes-Vidal, V.; Guijarro, E.; Balasch, S.; Torres, A. G. Application of computational fluid dynamics to the prediction of airflow in a mechanically ventilated commercial poultry building. Biosystems Engineering, v.100, p.105-116, 2008. https://doi.org/10.1016/j. biosystemseng.2008.02.004

Bustamante, E.; García-Diego, F.-J.; Calvet, S.; Estellés, F.; Beltrán, P.; Hospitaler, A.; Torres, A. G. Exploring ventilation efficiency in poultry buildings: The validation of computational fluid dynamics (CFD) in a cross mechanically ventilated broiler farm. Energies, v.6, p.2605-2623, 2013. https://doi.org/10.3390/en6052605

Bustamante, E.; García-Diego, F.-J.; Calvet, S.; Torres, A. G.; Hospitaler, A. Measurement and numerical simulation of air velocity in a tunnel-ventilated broiler house. Sustainability, v.7, p.2006-2085, 2015. https://doi.org/10.3390/su7022066

Carvalho, V. F.; Yanagi Junior, T.; Ferreira, L.; Damasceno, F. A.; Silva, M. P. Mapping of potential use of evaporative cooling systems in Southeastern Brazil. Revista Brasileira de Engenharia Agrícola e Ambiental, v.13, p.358-366, 2009. https://doi.org/10.1590/S141543662009000300020

Cobb Brasil. Manual de manejo de frangos de corte. São Paulo: Cobb Brasil, 2012. 70p.

Cunha, G. C. de A. Modelagem computacional da distribuição de variáveis ambientais em aviário ventilado à pressão negativa. Campina Grande: UFCG, 2017. 116p. Tese Doutorado

Curi, T. M. R. de C.; Conti, D.; Vercellino, R. do A.; Massari, J. M.; Moura, D. J. de; Souza, Z. M. de; Montanari, R. Positioning of sensors for control of ventilation systems in broiler house: A case study. Scientia Agricola, v.74, p.101-109, 2017a. https://doi. org/10.1590/1678-992x-2015-0369

Curi, T. M. R. de C.; Moura, D. J. de; Massari, J. M.; Mesquita, M.; Pereira, D. F. Computational fluid dynamics (CFD) application for ventilation studies in broiler houses. Engenharia Agrícola, v.37, p.1-12, 2017b. https://doi.org/10.1590/1809-4430-eng.agric. v37n1p1-12/2017

Curtis, S. E. Environmental management in animal agriculture. Ames: Iowa State University Press, 1983. 409p.

DCA - Departamento de Ciências Atmosféricas. Dados climatológicos do estado da Paraíba. Available on: <http://www.dca.ufcg.edu.br/ clima/dadospb.htm>. Accessed on: Jul. 2016. 
Franco, A.; Valera, D. L.; Peña, A.; Pérez, A. M. Aerodynamic analysis and CFD simulation of several cellulose evaporative cooling pads used in Mediterranean greenhouses. Computers and Eletronics in Agriculture, v.76, p.218-230, 2011. https://doi.org/10.1016/j. compag.2011.01.019

Furtado, D. A.; Azevedo, P. V. de; Tinôco, I. de F. F. Análise do conforto térmico em galpões avícolas com diferentes sistemas de acondicionamento. Revista Brasileira de Engenharia Agrícola e Ambiental, v.7, p.559-564, 2003. https://doi.org/10.1590/S141543662003000300025

Hernández, R. O.; Tinôco, I. de F. F.; Saraz, J. A. O.; Rocha, K. S. O.; Garcia, L. M. G. Modelamiento del ambiente térmico y aéreo de un galpón de presión negativa tipo túnel para pollitos. Revista Facultad Nacional de Agronomía Medellín, v.66, p.7085-7093, 2013.
Santos, M. B. G. dos. Índices bioclimáticos e produtivos em galpões para criação de frango de corte em alta densidade. Campina Grande: UFCG, 2012. 159p. Tese Doutorado

Saraz, J. A. O.; Tinôco, I. de F. F.; Rocha, K. S. O.; Martins, M. A.; Paula, M. O. de. Modeling and experimental validation to estimate the energy balance for a poultry house with misting cooling. Revista de Ingeniería Dyna, v.78, p.167-174, 2011.

Tao, X.; Xin, H. Acute synergistic effects of air temperature, humidity, and velocity on homeostasis of market-size broilers. Agricultural and Biosystems Engineering, v.46, p.491-497, 2003. https://doi. org/10.13031/2013.12971

Xue, H.; Qiang, Z.; Ni, J.-Q.; Baoming, L.; Zhengxiang, S.; Shumei, Z.; Yu, W. Effect of cooling pad installation on indoor airflow distribution in a tunnel-ventilated laying-hen house. International Journal of Agricultural \& Biological Engineering, v.9, p.169-177, 2016. 